\title{
TAJEMNICA WCIELENIA W NAJSTARSZEJ IKONOGRAFII CHRZEŚCIJAŃSKIEJ
}

Tajemnica wcielenia pojawiła się w sztuce chrześcijańskiej na początku IV wieku, w okresie tzw. ,przełomu konstantyńskiego”, w dekoracji seryjnie produkowanych w Rzymie kamiennych trumien (sarkofagów) ${ }^{1}$, a więc w twórczości sepulkralnej, przeznaczonej na użytek dość szerokiego grona nabywców. To, co mam do powiedzenia, będzie więc siłą rzeczy dotyczyło uproszczonego, może nawet w jakimś stopniu strywializowanego ujęcia tego tematu, którego teologiczną głębię ukazały nam poprzednie wystąpienia.

Zacznę od przypomnienia, ze tworzenie obrazu Boga było, w przekonaniu chrześcijan pierwszych wieków, równoznaczne z grzechem bałwochwalstwa, uważanego za „principale crimen generis humani”" W tym między innymi przejawia się wyższość religii chrześcijańskiej nad pogańską, że, wedle słów Justyna Męczennika: „Nie składamy żadnych ofiar ani wieńców bałwanom, jakie sobie ludzie utworzyli i poustawiawszy w świątyniach, nazwali „bogami”, ponieważ wiemy, że to tylko bezduszne i martwe przedmioty, kształtem swym do Boga niepodobne. Bóg - zdaniem naszym - jest zupełnie inny niż wszystkie owe wizerunki, w jakich się Go przedstawia dla kultu religijnego"3. U Orygenesa czytamy, że „chrześcijanie... brzydzą się świątyniami, ołtarzami i posągami bogów”, , a Klemens Aleksandryjski pisze, że „wzniosłość Boga doznaje poniżenia, jeśli się jest przyzwyczajonym mieć bez trudności w zasięgu wzroku Jego wizerunki",

Tego rodzaju zastrzeżenia odnosiły się jednak, jak się wydaje, przede wszystkim do wizerunków Boga Ojca, ponieważ już w pierwszych przedstawie-

Zob. J. Engemann, Untersuchungen zur sepulkral Symbolik der späteren römischen Kaiserzeit, Münster 1973, 78-85.

2 Por. Tertullianus, De idololatria 1,1, CCL 2, 1101; zob. B. Wronikowska, Poglady Ojców Kościoła na sztukẹ w okresie pierwszych dwóch stuleci istnienia Kościoła, RH 26(1978) z. 4, 5-12.

${ }^{3}$ Apologia I 9, PG 6, 340A, thum. M. Michalski, ALP I 93.

${ }^{4}$ Contra Celsum VII 64, GCS 3, 214, thum. S. Kalinkowski: Orygenes, Przeciw Celsusowi, Warszawa 1986, 378.

5 Stromata V 28,5, GCS 52, 344, thum. J. Niemirska-Pliszczyńska: Klemens Aleksandryjski, Kobierce II, Warszawa 1994, 26. 
niach sztuki chrześcijańskiej występują wyobrażenia tych postaci Trójcy Świętej, które, jak pisał Augustyn, „mogą się ukazywać oczom ludzi za pośrednictwem widzialnych stworzeń" wyobrażenia Ducha Świętego, pokazanego tak, jak w tekście ewangelii (Mt 3 , 16; Mk 1, 10; Łk 3, 22; J 1, 32), czyli pod postacią gołębicy. Widzimy także postać Chrystusa, który obecny jest w ikonografii chrześcijańskiej od początku, ale przedstawia się Go w sposób szczególny ${ }^{7}$. W najstarszych, datowanych na III wiek, obrazach, pokazywano Jezusa, ale zarazem i ukrywano - w znakach, symbolach, alegoriach ${ }^{8}$. Wszechobecne na ówczesnych, nie tylko chrześcijańskich, cmentarzach przedstawienia Dobrego Pasterza, stały się Jego najbardziej popularnym wyobrażeniem, ale wyobrażeniem symbolicznym, całkowicie abstrahującym od cielesności ${ }^{9}$. W III wieku Jezus występował też w malowidłach katakumbowych, w nielicznych jeszcze wówczas scenach inspirowanych tekstem Nowego Testamentu, jak np. wskrzeszenie Łazarza (np. w Kal 21 i 25, PiM 12,58$)^{10}$ czy rozmowa z Samarytanką (np. w Kal 22), w których starano się przekazać ważną prawdę, zawartą w słowach przez Niego wypowiedzianych. I to te słowa miały być za pośrednictwem obrazów przypomniane ${ }^{11}$. Zgodnie z regułami antycznej ikonografii, w scenie cudu wskrzeszenia pokazywano typ taumaturga (il. 1), a w rozmowie z Samarytanką postać mężczyzny, bez jakichkolwiek cech indywidualnych (il. 2$)^{12}$. Widzimy też w katakumbach (np. w PiM 58) Jezusa ubranego w tunikę i pallium, nauczającego, a zatem przedstawionego tak, jak wyobrażano antycznych mędrców i filozofów (il. 3$)^{13}$. Sama Jego postać i jej fizyczny wygląd były tu zdecydowanie nieistotne. Pełniły rolę znaku, takiego samego jak i pozostałe elementy przedstawienia, niezbędne dla jego czytelności. We wszystkich tych przedstawieniach tylko kontekst pozwala zidentyfikować jedną z występujących postaci z Jezusem.

${ }^{6}$ De Trinitate II 10,10, CCL 50, 103, tłum. M. Stokowska, POK 25, 133.

${ }^{7}$ Por. B. Iwaszkiewicz-Wronikowska, Jezus Chrystus, ikonografia, I: Wczesnochrześcijańska, EK VII 1409-1411.

${ }^{8}$ Por. J. Kollwitz, Das Christusbild des 3. Jahrhunderts, Münster 1953, s. 6: «an der Spitze der Geschichte des Christusbildes steht das Sinnbild».

${ }^{9}$ Por. A. Grabar, Les voies de la création en iconographie chrétienne. Antiquité et Moyen Age, Paris 1994, s. 26.

${ }^{10}$ Numeracja pomieszczeń katakumbowych za: A. Nestori, Repertorio topografico delle pitture delle catacombe romane, Città del Vaticano 1975.

11 We wspomnianych scenach były to zapewne słowa następujące: „Ja jestem zmartwychwstaniem i życiem! Kto wierzy we Mnie, chociażby nawet umarł, żyć będzie” (J 11,25) oraz „Kto tę wodę pije, będzie znowu pragnął. Kto zaś napije się tej wody, którą Ja mu dam, nigdy już nie zazna pragnienia. Ale woda, którą Ja mu dam, stanie się w nim źródłem wody tryskającej ku życiu wiecznemu" (J 4, 13-14) - cytaty biblijne za Biblią Tysiąclecia.

12 Por. J. Kollwitz, Christusbild, RAC III 1-24.

13 Por. P. Zanker, The Mask of Sokrates. The Image of the Intellectual in Antiquity, Berkeley 1995, 289-320. 
Takie ujęcie Jego postaci znakomicie koresponduje z tym, co na temat wyglądu Chrystusa znajdujemy w inspirowanych przez słynny passus Izajasza $(53,2 n)^{14}$ tekstach pisarzy pierwszych trzech wieków. Na przykład Tertulian pisał:

\begin{abstract}
„Ludzie widząc człowieka Chrystusa zdumiewali się tylko z powodu jego słów i czynów, tylko z powodu jego nauki i cnoty. Na pewno zostałoby to zapisane, gdyby coś niezwykłego w jego cielesności uznawano za cud. A przecież to nie cudowność jego ciała była tym, co czyniło jego wystąpienia tak zwracającymi na siebie uwagę, że mówili: «Skąd u Niego ta mądrość i cuda?» (Mt 13, 54). Mówili tak także ci, którzy gardzili jego postacią. Jego ciało nie posiadało więc po ludzku pięknej postaci, nie mówiąc już o niebiańskim blasku"15.
\end{abstract}

Również inni autorzy, jak np. Justyn ${ }^{16}$, Klemens Aleksandryjski ${ }^{17}$ i Orygenes $^{18}$, wspominając o wyglądzie Jezusa podkreślali, że nie miało znaczenia to, że nie był pięknym fizycznie ${ }^{19}$.

Zmianę przyniósł początek IV wieku. Nadal sam pomysł sporządzenia wizerunku Chrystusa szokował takich ludzi jak np. Euzebiusz z Cezarei ${ }^{20}$, a synod w Elwirze w kanonie 36 zabraniał przedstawiania tego, co było przedmiotem kultu ${ }^{21}$, ale równocześnie na tzw. sarkofagach fryzowych (m.in. tzw. „sarkofag córki Jaira”, sarkofag Marcii Romanii Celsy) $)^{22}$ pojawiło się nowe ujęcie postaci Jezusa z Nazaretu ${ }^{23}$. Pokazywano Go już w licznych, gęsto stłoczonych na fasadzie sarkofagu scenach, które znamy z relacji ewangelistów (il. 4). Były to przede wszystkim cudowne wydarzenia - przemiany wody w wino i rozmnożenia chleba, uzdrowienia, wskrzeszenia, zawsze odbywające się w towarzystwie świadków, którzy mogli potwierdzić, że wszystko to rzeczywiście miało miejsce. W przedstawieniach tych postać Jezusa nie była już tylko takim znakiem, jak Dobry Pasterz - alegoria odwołująca do całego bogactwa treści, jakie ludziom antyku kojarzyły się z tym obrazem. Nie była też, jak

${ }^{14}$ Por. Iz 53, 2: „Nie było w nim blasku ni piękna, byśmy w nim wzrok utkwić mieli, ani wyglądu, aby nas zachwycał”; zob. M. Kowalczyk, Jezus Chrystus, V: Charakterystyka postaci, I: Wygląd zewnętrzny, EK VII 1355.

${ }^{15}$ De carne Christi 9,5-6, CCL 2,892, thum. za: Jezus 2000 lat obecności, praca zbiorowa, thum. J. Grodecki - W. Zasiura, Warszawa 1999, 22.

${ }^{16}$ Por. Dialogus cum Judaeo Tryphone 14,8; 49,2.

${ }^{17}$ Por. Stromata II 22,8; III 103,3; VI 151,3; Paedagogus III 3,3.

${ }_{18}$ Por. Contra Celsum VI 75-77.

${ }^{19}$ Por. Kollwitz, Christusbild, 3-4.

${ }^{20}$ Por. Eusebius, Epistola ad Constantiam Augustam, PG 20, 1547-1548; zob. St. Gero, The True image of Christ: Eusebius letter to Constantia, JTS 32(1981) 460-470; H.G. Thümmel, Eusebios Brief an Kaiserin Konstantia, „Klio” 66(1984) 210-222 .

${ }^{21}$ Por. Concilium Eliberitanum can. 36, Mansi II 11, tłum. M. Starowieyski - M. Rola, WST 3(1985-1990) 198: „Uchwala się, że w kościele nie powinno być malowanych obrazów; aby nie malowano na ścianach tego, co się uwielbia (adoratur) i co się czci (colitur)".

22 Por. B. Filarska, Początki sztuki chrześcijańskiej, Lublin 1986, 157-159.

${ }^{23}$ Por. F. Gerke, Christus in der spätantiken Plastik, Mainz 1948, 12nn. 
w późniejszych mozaikach, wzorowana na pogańskim wizerunku „świętego męża" (theios aner) ${ }^{24}$. Na wczesnokonstantyńskich sarkofagach Chrystus pokazywany był jako postać historyczna, jako rzeczywiście istniejący i działający człowiek, ubrany tak, jak większość obecnych. Jednakże najwyraźniej nie był to człowiek taki sam, jak pozostali uczestnicy przedstawianych wydarzeń, ponieważ w znaczący sposób wyróżniał się w otaczającym Go tłumie. Ażeby tę różnicę pokazać, twórcy reliefów obdarzali Go wyrazistymi, indywidualnymi rysami pięknego młodzieńca o długich lokach (il. 5).

Po raz pierwszy pojawia się wówczas w ikonografii wizerunek Jezusa pokazanego w taki sposób, że nie potrzebny jest ani kontekst, ani dodatkowe atrybuty, ażeby Go zidentyfikować ${ }^{25}$ : nie mamy tu już wątpliwości, nawet widząc tylko fragment tego rodzaju przedstawienia, że ten piękny młodzieniec to Jezus. Nie sposób wobec tego uniknąc pytania o przyczynę tak radykalnej zmiany w ujęciu Jego postaci. Szukając odpowiedzi, nie możemy wykluczyć, że to tak właśnie, jako pięknego młodzieńca, wyobrażali Go sobie na początku IV wieku kamieniarze z rzymskich warsztatów. W apokryficznych Aktach Andrzeja, Mateusza, Jana i Piotra ${ }^{26}$, literaturze popularnej wówczas w szerokich kręgach chrześcijan, pisząc o Jezusie sięgano po inspirację już nie do Izajasza, lecz do Psalmu 45, w którym czytamy: „Tyś najpiękniejszy spośród synów człowieczych, wdzięk na Twych ustach rozlany” (Ps 45,3). Taką odpowiedź na postawione wyżej pytanie można uznać za wystarczającą, tym bardziej, że nie ma żadnych tekstów źródłowych, które nam wprost na to pytanie odpowiadają. Chciałabym jednak, zakładając, że twórcy tego nowego ujęcia postaci Jezusa mieli bardziej ambitny zamiar niż tylko realistyczne przedstawienie takiego Jezusa, jakim Go sobie wtedy wyobrażano, zaproponować inne wyjaśnienie: sądzę, że ich celem było pokazanie w ten sposób Jego zarówno ludzkiej, jak i boskiej natury ${ }^{27}$.

Nie ulega wątpliwości, że typ pięknego młodzieńca o charakterystycznej fryzurze, w postaci loków opadających na ramiona, nawiązuje do antycznego,

${ }^{24}$ Por. M. Andaloro, Christus praesens: l'icona. I prototipi pagani e l'archetipo del volto di Cristo, w: S. Ensoli - E. La Rocca (red.), Aurea Roma. Dalla città pagana alla città cristiana, Roma 2000, 413-415; P. Zanker, Dai filosofi ai santi e al ritratto di Cristo. Dal culto della „paideia” alla visione di Dio, tamże, s. 407-412..

25 Ten sposób przedstawiania utrzyma się i później, na sarkofagach dwufryzowych, powstających w okresie późnokonstantyńskim, np. na tzw. sarkofagu Dwóch Braci, gdzie nadal widzimy Jezusa w scenach dokonywania cudów i na tzw. Sarkofagu Dogmatycznym, gdzie towarzyszy Pierwszym Rodzicom, ale także na powstających w 2 pol. IV wieku sarkofagach kolumienkowych (np. J. Wilpert, I sarcofagi cristiani antichi, Roma 1929-1936 [= WS] 124, 2) i sarkofagach drzewnych (np. WS 227, 2).

${ }^{26}$ Por. Andrzeja i Mateusza (33) 23, ed. R. A. Lipsius - M. Bonnet, Acta Apostolorum Apocrypha, Hildesheim 1959 = Lipsius-Bonnet II 1,115, Z. 6, Jana (87) 23 (Lipsius-Bonnet, II 1, 193, Z. 25) czy Piotra (5) 23 (Lipsius-Bonnet I 51, Z. 1); zob. J. Sauer, Die ältesten Christusbilder, Berlin 1920, 2-3.

${ }^{27}$ Podobnie widział to Gerke, Christus, s. 19n. Zdaniem tego autora intencją artystów było „Christus als den einzigartigen Wundertäter zu charakterisieren” (tamże, s. 20). 
greckiego jeszcze, typu ikonograficznego przedstawień zwanych ,apollińskimi"28. Podobnie wyglądał zresztą w sztuce antycznej nie tylko Apollo, ale i Helios (il. 6), i Dionizos ${ }^{29}$ i Achilles ${ }^{30}$. Młodzieńcem o długich lokach był również Genius Populi Romani ${ }^{31}$. Tak też Rzymianie wyobrażali sobie niekiedy personifikacje pór roku ${ }^{32}$. Liczne przykłady tego typu przedstawień znajdujemy na przykład w reliefach sarkofagowych eksponowanych w Museo Nazionale delle Terme w Rzymie ${ }^{33}$. Skoro Chrystusa zaczęto przedstawiać na sarkofagach w taki sam sposób, jak poganie wyobrażali swoje bóstwa i swoich herosów, możemy domyślać się, że i On występuje tu nie tylko jako człowiek, uczestniczący w wydarzeniach historycznych, ale i jako Bóg (il. 7). Myślę, że to właśnie stworzenie wizerunku Chrystusa, w którym łączy się natura Boga $\mathrm{z}$ naturą człowieka, jest świadectwem dążenia do pokazania w ikonografii Tajemnicy Wcielenia ${ }^{34}$.

To nowe ujęcie postaci Chrystusa - Boga i Człowieka, eksponowane jest przede wszystkim w reliefach sarkofagowych, które w IV wieku przejęły od malowideł funkcję kreacyjną. Również na sarkofagach przede wszystkim ${ }^{35}$, a zwłaszcza na pokrywach sarkofagów produkowanych w warsztatach Rzymu w pierwszym trzydziestoleciu IV wieku ${ }^{36}$, widzimy „Słowo, które stało się ciałem”, tym razem w scenach biblijnych, tematycznie nawiązujących do Ta-

${ }^{28}$ Por. F. Gerke, La fin de l'art antique et les débuts de l'art chrétien, Paris 1967, s. 50: «la conception chrétienne de ce nouveau type du Christ se rapproche de l'idéal que l'époque se faisait de la beauté et de la force d'une représentation apollinienne».

${ }^{29}$ Por. E. Pochmarski, Das Bild des Dionysos in der Rundplastik der klassischen Zeit Griechenlands, Wien 1974.

${ }^{30}$ Por. D. Kemp-Lindemann, Darstellungen des Achilleus in griechischer und römischer Kunst, Berlin 1975.

${ }^{31}$ Por. H. Kunckel, Der römische Genius, Heidelberg 1974.

32 Gerke, zwracając uwagę na bliskie analogie między przedstawieniami pór roku na Łuku Konstantyna w Rzymie i przedstawieniami Jezusa na sarkofagach (np. Lat. 104 i 184) używa nawet na ich określenie terminu „Jahreszeiten - Christus” (Christus, s. 23); por. G. M.A. Hanfmann, The Season Sarcophagus in Dumbarton Oaks, Cambridge Mass. 1951, t. I, s. 215-219.

${ }^{33}$ Por. F. Gerke, Die christlichen Sarkophage der vorkonstantinischen Zeit, Berlin 1940, 228n; A. M. Reggiani Massarini, Museo Nazionale Romano. Salette e chiostro, Roma 1989, 25-29, 46.

${ }^{34}$ Inną ciekawą próbą uzyskania tego samego efektu są, być może, reliefy na tzw. Polichromowanych Fragmentach (w Palazzo Massimo w Rzymie), datowanych na lata około roku 300, gdzie, jak sądzi E. Dinkler (Christus und Asklepios. Zum Christustypus der polychromen Platten im Museo Nazionale Romano, Heidelberg 1981), przedstawiający Jezusa artysta wzorować się mógł na innym greckim typie ikonograficznym, tj. na wizerunkach Zeusa lub Asklepiosa. Takie wyjaśnienie nie znalazło jednak uznania w oczach większości badaczy, którzy raczej widzą tu jeden z wariantów typu filozofa - zob. Zanker, The Mask of Sokrates, s. 300.

${ }^{35}$ Przykłady scen o tej tematyce w malarstwie katakumbowym są nieliczne - zob. A. Nestori, Repertorio topografico delle pitture delle catacombe romane, II, edizione riveduta ed aggiornata, Città del Vaticano 1993, s. 191n, 194, 213.

${ }^{36}$ Por. W. Wischmeyer, Die Tafeldeckel der christlichen Sarkophage konstantinischer Zeit in Rom. Studien zur Struktur, Ikonographie und Epigraphik, Rom 1982, 106-108. 
jemnicy Wcielenia ${ }^{37}$. Starano się zobrazować ją za pośrednictwem trzech epizodów związanych z Bożym Narodzeniem: Pokłonu pasterzy, Pokłonu Magów (Mędrców ze Wschodu) i Proroctwa Balaama.

Ewa Tatar-Próchniak tak opisuje typowe dla pierwszego z tych tematów przedstawienie: „Maleńkie, owinięte ciasno pieluszkami Dzieciątko leżące w żłobie, pochylone nad nim zwierzęta wół i osioł, z boku jedna lub dwie męskie postacie w pasterskich strojach, czasem też drzewo w tle dla zaznaczenia, że akcja rozgrywa się w krajobrazie" 38 . Ponieważ Maryja jest w najstarszych tego rodzaju scenach nieobecna ${ }^{39}$, myślę, że należy tu widzieć, wbrew nadawanemu im na ogół tytułowi ${ }^{40}$, nie tyle samo Boże Narodzenie, co raczej opisane przez Łukasza (Łk 2, 8-18) i Protoewangelię Jakuba (17-20) objawienie Dzieciątka pasterzom, w obecności osła i wołu - zwierząt, które rozpoznały w Narodzonym Mesjasza (Iz 1, 3) $)^{41}$. Jest to więc raczej aluzja do faktu Bożego Narodzenia i próba pokazania jego teologicznej wymowy, niż ilustracja samego wydarzenia.

Temat Pokłonu Magów (Mt 2, 1-12; Protoewangelia Jakuba 21, 1-3) był obecny w okresie konstantyńskim na ścianach katakumb (m.in. Pri 39, PiM 4, $17,34,57,69)$ (il. 8) i na sarkofagach (il. 9) ${ }^{42}$, w przedstawieniach ukazujących dwóch lub trzech mężczyzn w strojach orientalnych, zbliżających się z darami do siedzącej na krześle Maryi z Dzieciątkiem na kolanach ${ }^{43}$. O popularności tego wątku świadczą stosunkowo liczne przedstawienia w sztuce wczesnochrześcijańskiej ${ }^{44}$.

${ }^{37}$ Por. G. Ristow, Die Geburt Christi in der frühchristlichen und byzantinisch-ostkirchlichen Kunst, Recklinghausen 1963, s. 6; tenże, Zur spätantiken Ikonographie der Geburt Christi, w: Spätantike und frühes Christentum. Ausstellung im Liebieghaus Museum Alter Plastik. Frankfurt am Main, 16. Dezember 1983 bis 11. März 1984, Frankfurt am Main 1984, 347-359; Lexikon der christlichen Iconographie, ed. E. Kirschbaum, = LCI II 86-120; P. Testini, Alle origini dell' iconografia di Giuseppe di Nazareth, RivAC 48(1972) 313-333; Milinović, art. cyt., s. 327-329; D. Milinović, L'origine de la scène de la nativité dans l'art paléochrétien (d'après les sarcophages d'occident). Catalogue et interprétation, „Antiquité Tardive” 7(1999) 299-329.

38 E. Tatar-Próchniak, Scena Narodzenia Chrystusa w ikonografii wczesnochrześcijańskiej, RTK 28(1981) z. 4, 189-196. Uderza w tym opisie nie tylko nieobecność Maryi, która pojawi się w scenie narodzin dopiero w drugiej połowie IV wieku (G. Bovini $-\mathrm{H}$. Brandenburg $-\mathrm{F}$. W. Deichmann, Repertorium der christlich-antiken Sarkophage, Bd. I: Rom und Ostia, Wiesbaden 1967 = Rep. I. 28) i Józefa, którego będzie się przedstawiać jeszcze później, bo od V wieku (zob. Testini, art. cyt., s. 271-347).

${ }^{39} \mathrm{~Np}$. Rep. I 11, 13, 649, 771; zob. też: C. Conidi, L'arcosolio di presepe nel cimitero di San Sebastiano, RivAC 73(1997) 95-112.

${ }^{40}$ Por. m.in. G. A. Wellen, Theotokos. Eine ikonographische Abhandlung über das Gottesmutterbild in frühchristlicher Zeit, Utrecht/Antwerpen 1961, s.14; Ristow, Die Geburt, s. 11nn; L. Kötzsche - Breitenbruch, Geburt III. B. Christlich, RAC IX 197: „Die frühchristl. Kunst Roms stellte nicht den Vorgang der G. Christi dar, sondern veranschaulichte das Erscheinen des göttlichen Kindes in der Welt durch andere Szenen".

${ }^{41}$ Por. Anbetung der Hirten, w: H. Aurenhammer, Lexikon der christliche Ikonographie, I, Wien 1967, 108-111.

${ }^{42}$ Por. Rep. I 5, 11, 16, 33, 41, 43, 96, 135, 145, 161, 241, 257, 625, 692, 770. 
Niekiedy scenę Pokłonu Magów uzupełniają dodatkowe motywy. Na uwagę zasługuje zwłaszcza gwiazda, wspomniana w starotestamentowym proroctwie ( $\mathrm{Lb} 24,17)^{45}$. Czasami pojawia się również mężczyzna, wskazujący gwiazdę prawą ręką, jak na przykład na płycie z epitafium Sewery (il. 10) ${ }^{46}$. Taka postać występuje też bez kontekstu, na kilku późniejszych nieco freskach katakumbowych (PiM 42, 46, 53, 62; Lat 13), a także w katakumbie Pryscylli (Pri 10), gdzie towarzyszy kobiecie trzymającej dziecko w ramionach, zgodnie uważanej za najstarsze znane przedstawienie Maryi z Dzieciątkiem ${ }^{47}$. Identyfikacja mężczyzny budziła przez dłuższy czas wątpliwości, na ogół uważano go za Józefa ${ }^{48}$ lub Izajasza ${ }^{49}$. Jednak obecnie ${ }^{50}$ większość badaczy zgadza się, że należy widzieć w nim Balaama ${ }^{51}$, pogańskiego proroka, który przepowiedział wzejście gwiazdy z pokolenia Jakuba (Lb 24, 17), co, jak wiadomo, tłumaczone było przez Ojców jako proroctwo wcielenia Chrystusa ${ }^{52}$, albo uznaje, że jest to symboliczne wyobrażenie proroctwa mesjańskiego ${ }^{53}$, zawierającego różne zapowiedzi Narodzin Chrystusa ${ }^{54}$.

43 Antyczne prototypy tej sceny zob. E. Jastrzębowska, Das antike Erbe in der Ikonographie der Kindheitsevangelien Christi, „Boreas” 16(1993) 115n; taż, Die Boten, Magier und Pilger, „Boreas” 17(1994) 105-113.

44 Por. WS II 279-289; Rep. I 11, 135.

${ }^{45}$ Por. Rep I. 5; Grabar, dz. cyt., s. 226: „L'étoile est le symbole de la grace descendant sur Marie..."; F.W. Deichmann, Zur Erscheinung des Sternes von Bethlehem, w: Vivarium, Münster 1984, s. 8-9: „er muss bei der Mehrzahl der Beispiele [...] als der Stern aus Jakob verstanden werden".

${ }^{46}$ Por. E. Kirschbaum, Eine vergessene altchristliche Gemme und das Epitaph der Severa, RivAC 42(1966) 189-200.

${ }^{47}$ Por. J. Wilpert, Die Malereien der Katakomben Roms, Freiburg i. Br. 1903 [= WM] 21-22; F. Bisconti, La Madonna di Priscilla: interventi di restauro ed ipotesi sulla dinamica decorativa, RivAC 72(1996) 7-34.

${ }^{48}$ Por. Testini, art. cyt., s. $273 \mathrm{nn}$.

49 Por. G. B. De Rossi, Immagini scelte della B. Vergine Maria tratte dalle catacombe Romane, Roma 1863, s. 7-8; J. Wilpert, La divina maternità di Maria Vergine e il Profeta Isaia (Is. 7, 14 e 60, 1 6), RivAC 11(1934) 152-155.

${ }^{50}$ Od czasu opublikowania artykułu Engelberta Kirschbauma, Der Prophet Balaam und die Anbetung der Weisen, RQ 49(1954) 129-171. Taką interpretację proponował już R. Garrucci, Storia dell'arte cristiana, II, Prato 1873, s. 87; zob. też Testini, art. cyt., s. 271-347; D. Calcagnini Carletti, Nota iconografica: la stella e il vaticinio del V.T. nell'iconografia funeraria del III e IV sec., RivAC 64(1988) 65-87.

${ }^{51}$ Do wyjątków należy G. Otranto, Tra esegesi patristica e iconografia: il personaggio maschile in una scena di Priscilla, „Vetera Christianorum” 20(1983) 305-328, który identyfikuje tę postać z Dawidem.

${ }^{52}$ Por. Justinus, Apologia I 32-33; Irenaeus, Adversus haereses III 9, 2 i III 83; Origenes, In Numeros hom. 18, 34 i Contra Celsum I 59.

${ }^{53}$ Np. F. Bisconti opowiedział się za tą wysuniętą wcześniej (L. De Bruyne, Les ,,lois” de lart. paléochrétien comme instrument herméneutique, „Rivista di Archeologia Cristiana” 39(1963) s. 74n, 91; Testini, art. cyt., przyp. 6) koncepcją ,,che individua nella figura una sorta di personificazione della profezia e non un profeta particolare" (art. cyt., s. 23). 
Ojcowie pierwszych trzech wieków, jak się wydaje, pisząc o Narodzeniu podkreślali przede wszystkim wypełnienie starotestamentowego proroctwa ${ }^{55}$. Dopiero początek IV wieku przyniósł pojawienie się głębszej refleksji teologicznej nad znaczeniem inkarnacyjnego aspektu tego faktu. A więc, sceny Pokłonu pasterzy i Magów pokazywać miały już nie tylko wypełnienie proroctwa, ale, i to w pierwszym rzędzie, objawienie Boga w ciele człowieka.

Kończąc ten krótki z konieczności szkic ukazujący początki ikonografii Tajemnicy Wcielenia, chciałabym, słowami Ewy Bieńkowskiej, zwrócić uwagę na niewyobrażalne wręcz skutki, jakie miał fakt podjęcia tego tematu przez artystów chrześcijańskich: „Dogmat o Wcieleniu - podstawa sakralna i metafizyczna sztuki naszej cywilizacji - usprawiedliwiał potrzebę widzialności, wizualizacji, podobnie jak ustanawiał godność innych gałęzi twórczości. Słowo Wcielone to już sam w sobie niezmierzony program dla sztuk pracujących w tworzywie zmysłowym, chwytających duchowość w sieć percepcji, przedstawiających ją jako duchowość widzialną, słyszalną, dotykalną"56.

\title{
IL MISTERO DELL'INCARNAZIONE NELLA PIU ANTICA ICONOGRAFIA CRISTIANA
}

\author{
(Riassunto)
}

Il tema dell'Incarnazione appare nell'iconografia cristiana all'inizio del IV secolo rappresentato soprattutto nei bassorilievi sui sarcofagi. Cristo, raffigurato precedentemente come Buon Pastore o taumaturgo senza i tratti fisionomici individuali, vi appare come un personaggio storico delle scene descritte dagli evangelisti essendo, nel contempo, una figura particolare, da distinguersi dagli altri partecipanti degli eventi grazie ai tratti del viso particolarmente belli e ai capelli lunghi, caratteristiche affini al tipo iconografico degli antichi dei e degli eroi (p.e. Apollo, Elios, Dionisio, Achille). Gesù è quindi raffigurato allo stesso tempo come uomo e Dio. Altre scene connesse all'evento dell'Incarnazione sono tre episodi collegati con la storia della Nascita di Gesù: il saluto dei pastori, l'omaggio dei magi e la profezia di Balaam, che rappresentano l'apparizione del Dio nel uomo.

\footnotetext{
${ }^{54}$ Calcagnini Carletti, art. cyt., s. 65-87.

55 G. Ristow, Zur spätantiken Ikonographie der Geburt Christi, s. 347.

${ }^{56}$ E. Bieńkowska, Co mówią kamienie Wenecji, Gdańsk 2000, 114.
} 


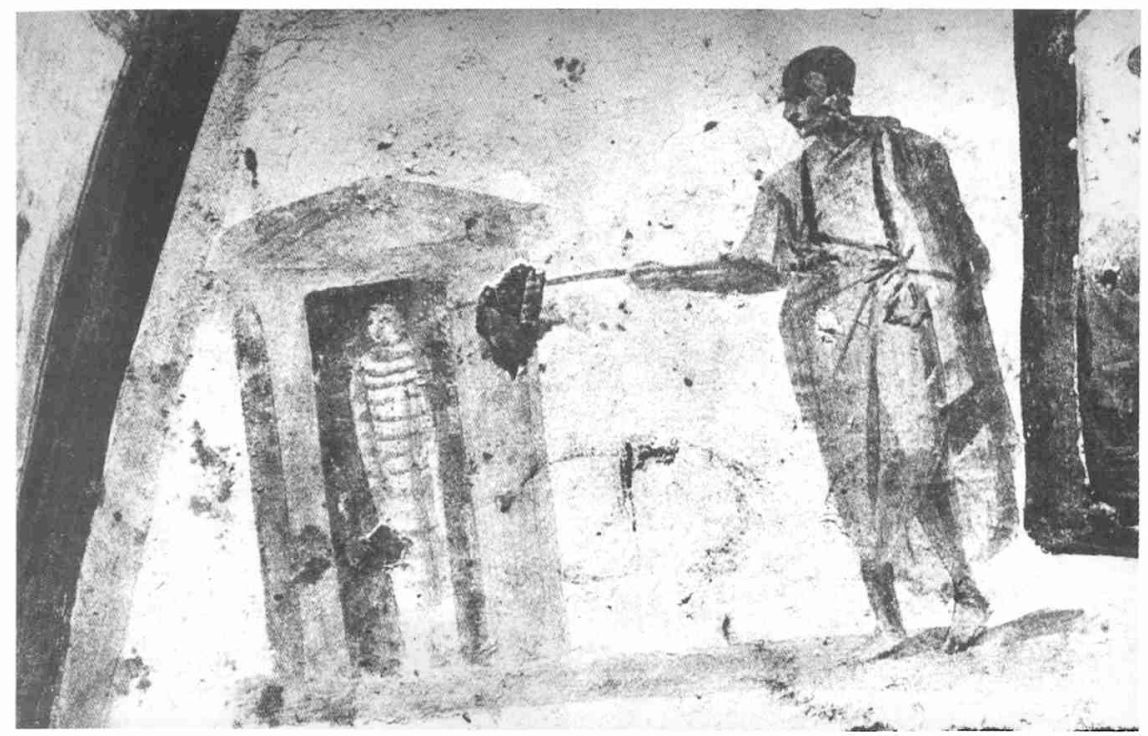

1. Wskrzeszenie Łazarza (Malowidło z katakumb przy Via Anapo)

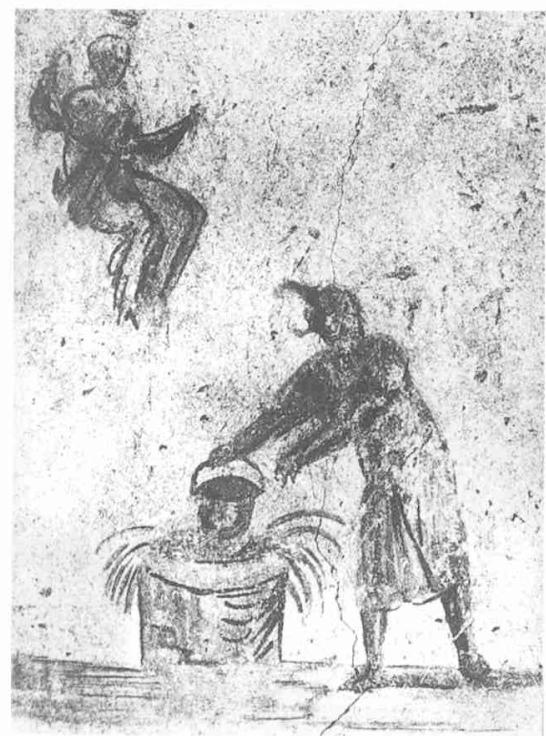

2. Rozmowa z Samarytanką (Malowidło z katakumb św. Kaliksta)

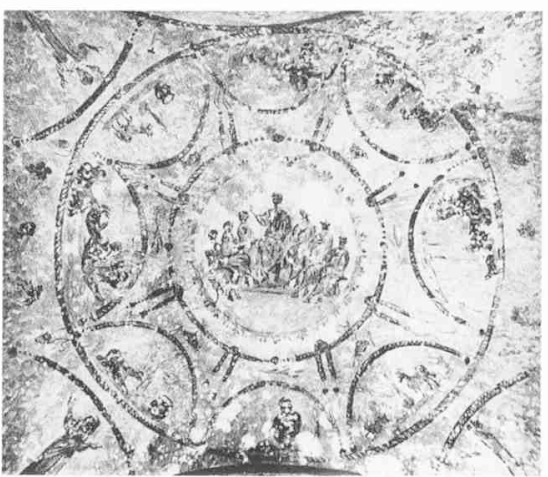

3. Chrystus z uczniami

(Malowidło z katakumb Marcelina i Piotra) 


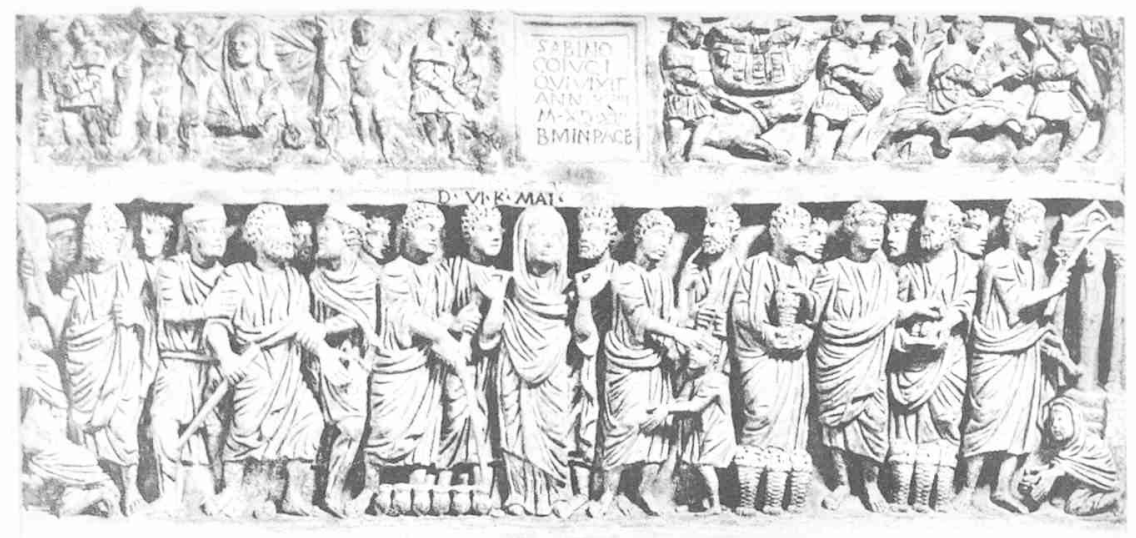

4. Sceny z Nowego Testamentu (Sarkofag Sabinusa)

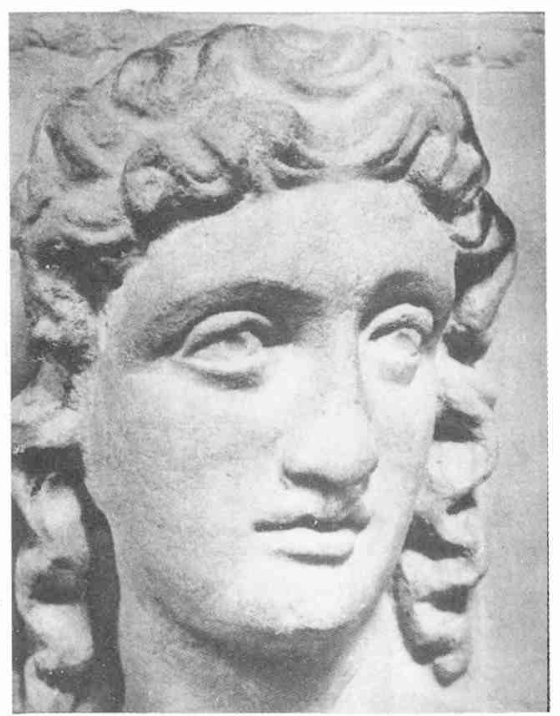

5. Wizerunek Jezusa

(Sarkofag Lat. 174, fragm.)

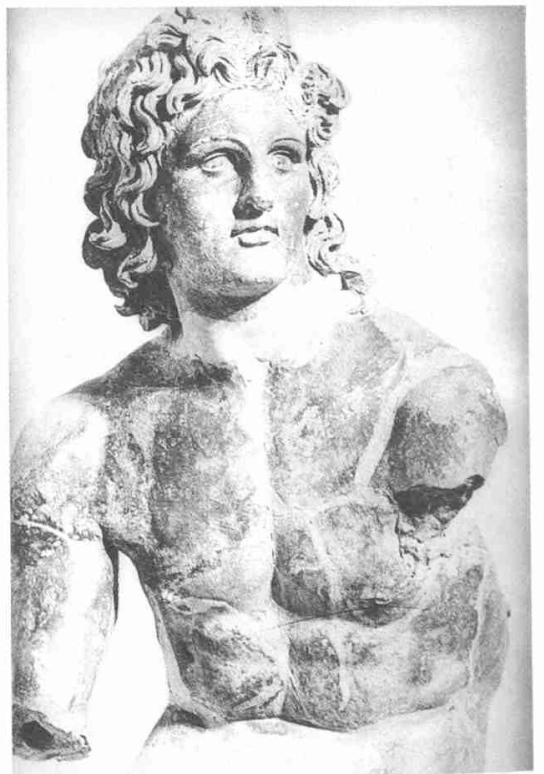

6. Tors Apollina, koniec III w. prz. Chr. (Villa Giulia, Rzym) 


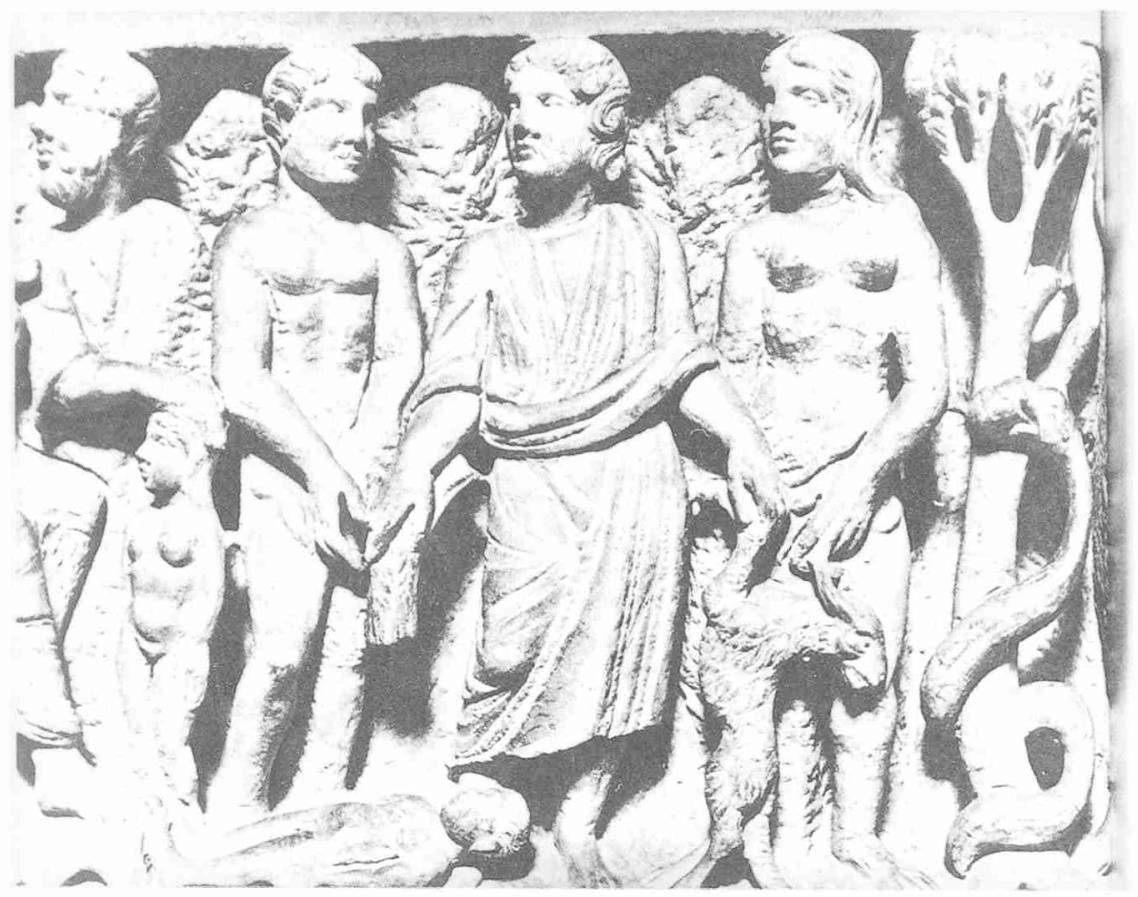

7. Chrystus z Adamem i Ewą (Sarkofag „dogmatyczny”, frgm.)

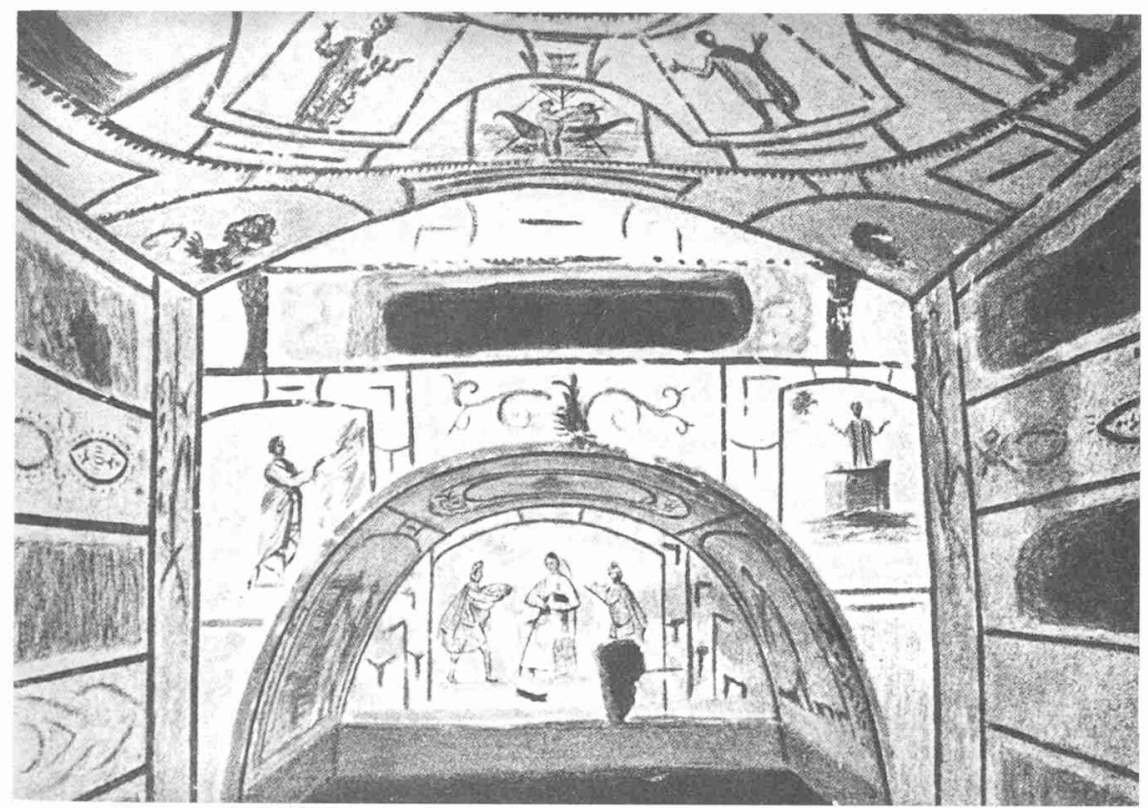

8. Pokłon Magów (Malowidło z katakumb Marcelina i Piotra) 


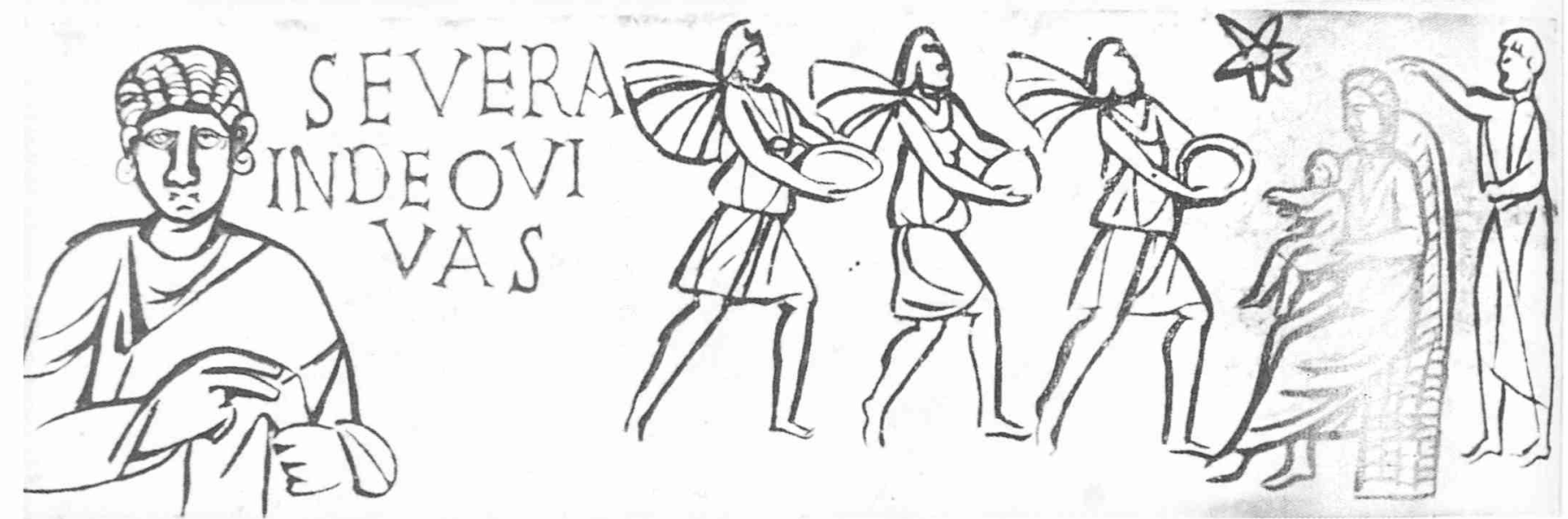

9. Pokłon Magów (Pokrywa sarkofagowa z Museo Nazionale Romano)

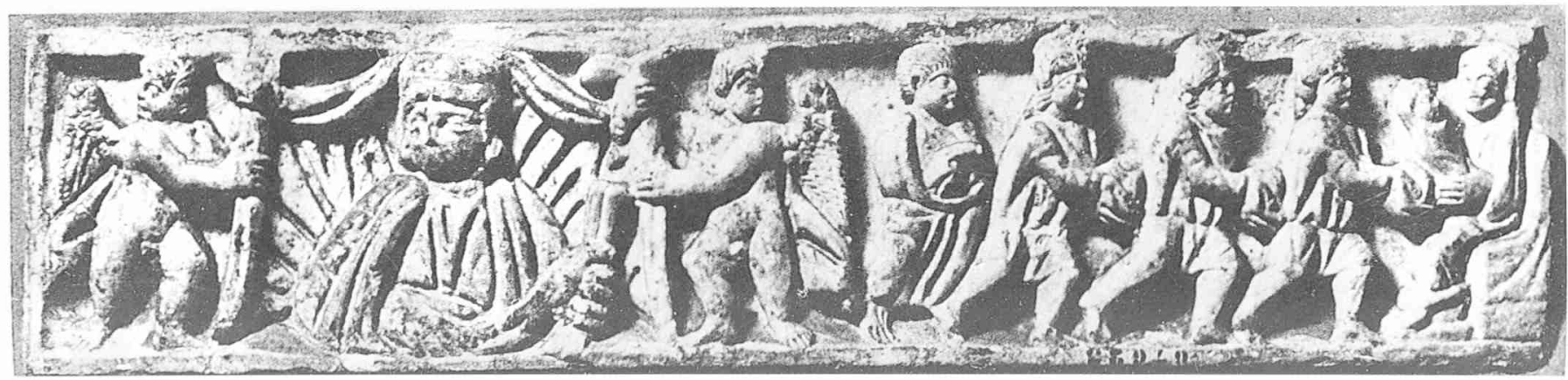

10. Pokłon Magów (Epitafium Sewery) 